Araştırma Makalesi / Research Article

\title{
OLUMLU VE OLUMSUZ AĞIZDAN AĞIZA YAPILAN MÜŞTERİ ŞİKÂYETLERİ: OTOMOTIV SEKTÖRÜNDE UYGULAMA
}

\author{
Hülya ER*
}

Ruziye COP**

\section{CUSTOMER COMPLAINTS IN THE FORM OF POSITIVE AND NEGATIVE WORD-OF-MOUTH COMMUNICATION: AN APPLICATION IN THE AUTOMATIVE SECTOR}

\author{
$\ddot{O} \mathbf{z}$
}

$\mathrm{Bu}$ çalışmanın amacı, cevaplayıcıların demografik özellikleri ile olumlu ve olumsuz ağızdan ağıza yapılan şikâyetler ve şikâyet sonrası oluşan müşteri tatmini arasında farklılıklar olup olmadığını ve şikâyetleri ele alış şekillerini öğrenmektir. Çalışmaya katılan cevaplayıcıların demografik özellikleri ve şikâyet süreci ile ilgili bilgilerini öğrenmek için frekans analizi yapılmıştır. Ölçek maddelerinin geçerlilik ve güvenilirliği bulunmuş ve faktör analizi ile analiz edilmiştir. Demografik değişkenlere ve şikâyet nedenlere göre farklılık gösterme durumu ise Mann Whitney ve Kruskal Wallis testleri ile analiz edilmiştir. Araştırma sonucunda, cevaplayıcıların çoğunluğunun fiyatların yüksek olmasından şikâyetçi olduğu ortaya çıkmıştır. Cevaplayıcıların çoğunluğu, işletmede yaşadığı şikâyetlerini çevresine olumsuz ağızdan ağıza şikâyet yoluyla ortalama 10 ve üstü kişiye anlattığ görülmektedir. Son olarak cevaplayıcıların demografik özellikleri ve şikâyet nedenleri ile olumlu ve olumsuz ağızdan ağıza yapılan şikâyetler arasında istatistiksel olarak anlamlı farkl11ıklar tespit edilmiştir.

Anahtar Kelimeler: Müşteri Şikâyetleri, Ağızdan Ağıza İletişim, Olumsuz Ağızdan Ağıza Şikâyet, Müşteri Tatmini.

\begin{abstract}
This study aimed to determine whether participants differed in their positive and negative word-of-mouth communication and customer satisfaction following complaint in terms of their demographic attributes, as well as to determine how participants voice their complaints. Frequency analysis was conducted to find out
\end{abstract}

* Öğr. Gör., Bolu Abant İzzet Baysal Üniversitesi, Bolu MYO, Bankacılık ve Sigortac1lık Bölümü, e-posta: hulyaer@ibu.edu.tr, https://orcid.org/0000-00023715-2433.

** Prof. Dr., Bolu Abant İzzet Baysal Üniversitesi, İİB, İşletme Bölümü, eposta: cop_r@ibu.edu.tr, https://orcid.org/0000-0002-2053-2157.

Makale Gönderim Tarihi : 13.05.2019 https://doi.org/10.11616/basbed.v19i49542.564241 Makale Kabul Tarihi $\quad: 12.09 .2019$ 
participants' demographics and their process of complaint. Validitiy and reliability of the items in the scale were calculated and examined through factor analysis. Differences in demographic attirbutes and reasons for complaint were analyzed through Mann Whitney and Kruskal Wallis tests. The findings of the present study suggested that the majority of the complaints of the participants were due to high prices. It was found that most of the study participants told an average of ten people or more about the problems they experienced in the business through negative word-of-mouth communication. Finally, statistically significant differences were found between customers' demographic attributes and reasons for complaint and complaints in the form of positive and negative word-of-mouth communication.

Keywords: Customer Complaints, Word-Of-Mouth Communication, Negative Word-Of-Mouth Complaint, Customer Satisfaction.

\section{Giriş}

Günümüzün yoğun rekabet ortamında müşteri odaklı pazarlama anlayışını benimseyen işletmelerin varlığını sürdürebilmeleri ve gelişebilmeleri için satış ve satış sonrası hizmetlerde müşteri memnuniyeti sağlamaları işletmelerin başarısı için temel bir faktördür. İşletmeler mal veya hizmetleri için tüketiciler üzerine yoğunlaşarak başarılı bir pazarlama stratejisi oluşturabilirler. Teknolojinin hızla gelişmesi, yeni mal veya hizmetlerin ortaya çıkması pazarlama koşullarını değiştirmiştir. Mal veya hizmet çeşitliliği ile müşteri beklentilerinin artması nedeniyle tüketicilerin istek ve ihtiyaçlarını karşılamak ve tüketicilerin şikâyetlerini azaltmak işletmelerin öncelikli amaçları haline gelmiştir.

Tüketicilerin satın alma kararlarını verirken günlük hayatta edindiği yoğun bilgi miktarı, pazarda tüketicinin ihtiyacını karşılayacak mal veya hizmet miktarının çeşitliliği, tüketicinin satın alma kararını zorlaştırmakta ve kısa yoldan güvenilir bilgiye ulaşabilme ihtiyacını ortaya çıkarmaktadır. $\mathrm{Bu}$ güvenilir bilgiye ulaşabilmek için tüketiciler arası en önemli etkileşim araçlarından birisi de ağızdan ağıza şikâyettir. Kişiler satın aldıkları mal veya hizmetler hakkında ağızdan ağıza şikâyet yoluyla olumsuz veya olumlu etkilerde bulunarak diğerlerinin satın alma kararlarını etkilemektedir (Anderson, 1998: 5). Satış sonrasında memnun olan müşteriler işletmeden mal ve hizmet satın almaya devam ederken işletmeye bağlılığını sürdürür hem de çevresine olumlu düşüncelerini söyleyerek de işletmeye katkı sağlarlar. Memnun olmayan müşteriler ise genellikle, şikâyette bulunarak veya yaşadıkları olumsuz deneyimlerini olumsuz ağızdan ağıza şikâyet yoluyla çevresindeki kişilerle paylaşmaktadırlar (Zeelenberg ve Pieters, 1999: 90). 
Olumsuz ağızdan ağıza şikâyetin kişileri etkileme konusunda olumlu ağızdan ağıza şikâyetten daha fazla etkili olduğu yapılan birçok çalışmada ortaya konmuştur. Müşterilerin şikâyetlerinin işletmeler tarafından anlaşıldıktan sonra etkili bir şekilde ele alınıp çözülmesiyle, müşteri memnuniyeti ile müşteri sadakatini artmakta ve işletmelere tüketicinin beklentilerine göre mal veya hizmet verme imkânını sağlamaktadır. Müşteri şikâyetlerinin işletmeler tarafından dikkate alınmamasın da ise, olumsuz ağızdan ağıza şikâyet yoluyla işletme zarar görebilmekte ve mali sıkıntılar yaşayabilmektedir. Bundan dolayı yöneticilerin olumsuz ağızdan ağıza şikâyetin ortaya çıkmasına yol açacak durumu önceden tespit edip bu olumsuzluğu önleyecek, olumlu ağızdan ağıza şikâyeti başlatmaları gerekmektedir. Olumlu ağızdan ağıza şikâyet nedeniyle de müşterilerin işletmelerden tekrar mal veya hizmet satın alması kolaylaşabilecek, müşteri tatmini sağlanacak ve böylelikle müşteriler satın aldıkları mal veya hizmet deneyimlerini çevresine anlatacak, hatta onları ikna etmeye çalışacaklardır. Böylece işletme yeni müşteriler kazanabilecektir.

Bu çalışmanın amacı, cevaplayıcıların demografik özellikleri ile olumlu ve olumsuz ağızdan ağıza yapılan şikâyetler ve şikâyet sonrası oluşan müşteri tatmini arasında farklılıklar olup olmadığını ve şikâyetleri ele alış şekillerini öğrenmektir. Bu çalışma olumlu ve olumsuz ağızdan ağıza yapılan müşteri şikâyetleri ile ilgili işletmelere bilgi verme ve daha sonra çalışma yapacaklara kaynak olması açısından önemlidir.

\section{Literatür Taraması}

\subsection{Müşteri Şikâyetleri}

Müşteri arzu ve ihtiyaçlarının tam olarak karşılanmaması, mal ya da hizmet sunumunda herhangi bir kusurun ortaya çıkması veya satın alma sonrası süreçte yaşanan aksaklıklar gibi nedenlerden dolayı müşteriler şikâyet edebilmektedirler (Varinli ve Çatı, 2010: 119). Bir mal veya hizmet almak isteyen müşterinin beklentisinin karşılanmaması durumunda şikâyetin başlangıcı söz konusudur (Lapré ve Tsikriktsis, 2006: 352). Şikâyet, bir mal veya hizmet ile ilgili olumsuz düşüncelerin müşteri tarafından geri bildirimidir (Bell, Mengüç ve Stefani, 2004: 113).

Şikâyetler, işletmelerin durumunu iyileştirmek için mesaj verirler. Şikâyetler olmadığında küçük sorunlar, aksilikler zamanla büyüyerek büyük sorunlara yol açmadan tespit edilemez ve çözülemezler (Kozak, 2006: 13). Şikâyette bulunan müşteri hala işletmenin müş̧erisidir, ancak çoğu durumda müşterinin işletmeyi terk edip başka işletmeye geçmesi her 
an mümkündür. Şikâyetini dile getiren müşteri işletmeyi hala önemsiyor olduğunu göstermektedir (Barlow ve Moller, 2009: 23).

Müşteri şikâyet yönetimi, müşterinin satın aldığı mal veya hizmet sonucu karşılaştıkları sorunların ortaya çıkarılması ve çözülmesi ile gelecekte meydana gelmesinin engellenmesi ile ilgili süreçleri kapsamaktadır (Gökdeniz, Bozacı ve Karakaya, 2011: 175). İşletmelerin şikâyet eden müşterilerin sorunlarını çözmenin yanı sıra aynı sorunlar ile bir daha karşılaşmamak için şikâyet yönetimi anlayışını benimsemeleri gerekmektedir (Barış, 2008: 15). İşletmeler müş̧eri şikâyet yönetimi üzerine odaklanırlarsa pek çok fayda sağlayacaklardır (Harrison-Walker, 2001: 401). İşletmelerin şikâyetleri iyi kullanılabilmesi müşteri şikâyetlerine yönelik tutumu ile bağlantılıdır (Eşkinat, 2009: 31). İşletmeler eğer müşteri şikâyet yönetimi ile tatmin olmayan müşterilerini tatmin ederlerse, müșterilerini elde tutabilir ve geri kazanabilirler (Brouard ve Larivet, 2010: 540). Bu nedenle müşteri şikâyetleri işletmelerin hatalarını öğrenebilmeleri, müşterilerine yönelik stratejiler geliştirmeleri için iyi bir firsat olarak değerlendirilmelidir.

Müşteri şikâyetleri ile ilgili yapılan çalışmalar incelendiğinde; Day ve Landon (1976) yaptıkları çalışmada, müşteriler şikâyet davranışları olarak söylemek istediklerini olumsuz ă̆ızdan ağıza şikâyet yoluyla duyurma şeklinde eylemlerde bulunduklarını ortaya koymuşlardır. Manickas ve Shea (1997), New York şehrinde lüks bir otelde yaptıkları bir çalışmada 220 şikâyet kaydını incelemişler ve erkeklerin kadınlardan daha fazla şikâyet davranışı gösterdikleri belirtilmiştir. Davidow ve Dacin (1997) tarafından yapılan bir çalışmada, genellikle müşterilerin ve işletmelerin arasındaki değişimde müşteri şikâyet davranışlarını ele almışlardır. Müşteri ve işletme arasındaki değişimde, memnun veya memnun olmayan müşterileri belirlenerek müşteri şikâyet davranışlarını oluşturan nedenleri ortaya koymaya çalışmışlardır. Verimli bir şikâyet yönetimi oluşturmak, işletmeye şikâyet iletmeyen müşterileri teşvik etmek ve gerekli stratejileri ortaya koyabilmek için işletmeleri incelemişlerdir. Sonuçta, şikâyeti teşvik etmek ile ilgili değişkenler üzerine odaklanmış, verimli müşteri şikâyet oluşturma programları ve işletmeye yardım etmede daha etkili olacak şikâyeti ele alma yöntemleri üzerinde çalışmışlardır.

Strauss ve Hill (2001) yaptıkları çalışmada, etkili müşteri şikâyet aracı olarak yüz yüze, mail, telefon yoluyla yapılan şikâyetleri incelemişlerdir. Uzun dönemli müşteri ilişkileri ve müşteri memnuniyetini artırmak açısından şikâyetlere bakmışlardır. İşletmelerin \%47 oranında müşterilerin şikâyetlerini e-posta yoluyla ilettiğini belirtmişlerdir. Hızlı bir şekilde e-postaları yanıtlayan işletmelerin müşteri memnuniyetinin 
satın almalarının ve olumlu algılarının artığını gözlemlemişlerdir. Heung ve Lam (2003)ise, otel restoran bölümündeki müşterilerin şikâyet davranışını incelemişlerdir. Araştırma sonucunda, kadınların, gençlerin ve eğitim düzeyi yüksek olan müssterilerin diğerlerine göre daha fazla şikâyet eğiliminde olduğunu tespit etmişlerdir. Ayrıca müşterilerin şikâyetleri iki seviyede sınıflandırılmıştır. Bunlar eyleme geçme veya eyleme geçmeme. Eyleme geçmemenin nedenlerinden en önemlisinin harekete geçmenin zaman ve çabaya değmeyeceği düşüncesi olduğunu ortaya koymuşlardır.

Phau ve Sari (2004), yaptıkları araştırmada demografik faktörlerin şikâyet davranışını etkilediğini ve şikâyet etmeyen müşterilerin şikâyet edenlerden daha tehlikeli olduğunu belirtmişlerdir. Ayrıca, araştırma sonucunda müşterilerin \%46'sının şikâyet etmedikleri, ancak bu kötü deneyimlerini ailesine ve çevresine bahsettiklerini ortaya koymuşlardır. Sujithamrak ve Lam (2005) tarafindan yapılan bir çalışmada otel restoranlarında müşteri şikâyet davranışları ile demografik özellikler arasındaki ilişkiyi incelemişlerdir. 250 otel restoranı müşterisi üzerinde yapılan çalışmaya göre, yaşlı, eğitim ve gelir düzeyi yüksek, müşterilerin genç, eğitim ve gelir düzeyi düşük olan müşterilerden daha çok şikâyet etme eğiliminde oldukları bulmuşlardır. Ayrıca müşterilerin oluşan şikâyetlerini olumsuz ağızdan ağıza şikâyet yoluyla arkadaşlarına, ailesine ve çevresine anlatarak o otele gitmelerini engelledikleri tespit edilmişlerdir.

Ngai, Heung, Wong ve Chan (2007) yaptıkları çalışmada, Asya ve Asya dışındaki otel misafirlerini kültür boyutları açısından müşteri şikâyet davranışları arasındaki farklı1ıklarını test etmişlerdir. Asyalı müşteriler Asyalı olmayan müşterilerden daha az şikâyette bulunduğu görülmüş ve şikâyet eyleminde bulunmayan Asyalı müşterilerin olumsuz ağızdan ağıza şikâyet yoluyla şikâyetlerini dile getirdikleri ve şikâyet teşvik faktörü ile şikâyet davranışı arasındaki ilişkinin önemli olduğu tespit etmişlerdir. Olcay ve Sürme (2014) yaptıkları çalışmada, Gaziantep’te faaliyette olan otel işletmesinde müşteri şikâyetleri ve eğitim düzeyinin şikâyetler üzerinde herhangi bir etkisi olup olmadığını araştırmışlardır. 406 otel müşterisine yapılan anket sonucuna göre, oda konforu ve temizliği, yiyecek-içecek, çalışan ve otel genel hizmetleri gibi şikâyetlerin olduğunu ancak müşterilerin genel olarak aldıkları hizmetlerden memnun olduklarını belirlenmiştir. Ayrıca, şikâyet etme durumu ile eğitim düzeyi arasında anlamlı bir farklılık bulunmadığını ortaya koymuşlardır.

Müşteriler işletmeden satın aldıkları mal veya hizmetten memnun ise olumlu ağızdan ağza iletişimle meşgul olurken, memnun olmayan 
müşteriler ise olumsuz ağızdan ağza iletişimin yayılması için harekete geçmektedir (Naylor ve Kleiser, 2000: 27). Olumsuz ağızdan ağıza yapılan müşteri şikâyet davranışları ve memnuniyetsizlik üzerine odaklanmaktadır (Molinari, Abratt ve Dion, 2008: 365). Bu durumda işletmeler için önemli bir tehdit oluşturabilmektedir (Karaca, 2010: 58). $\mathrm{Bu}$ nedenle tatmin olmayan müşterilerin şikâyetleri işletme tarafindan dikkatlice ele alınarak ve gereken şekilde değerlendirilerek uygun çözüm yollarının bulunması ile bu tehdidi en aza indirmek için etkili müşteri şikâyet yönetimi oluşturması gerekmektedir (Varinli ve Çatı, 2010: 121).

Olumsuz ağızdan ağıza şikâyet ile ilgili yapılan çalışmalar incelendiğinde; Anderson (1998) yaptığ çalışmada, tüketici tatmini ve ağızdan ağıza şikâyeti araştırmıştır. Araştırma sonucuna göre, tatmin olmayan müşteri tatmin olan müşterilerden daha fazla olumsuz ağızdan ağıza şikâyet yaptığını ortaya koymuştur. Tatmin olmayan müşterilerin yaptıkları olumsuz ağızdan ağıza şikâyetler haksız mal ya da hizmeti karalayıcı nitelikte olduğunu belirtilmiş̧ir. Harrison-Walker (2001) yaptı̆̆ ağıza şikâyetin başlaması için yeterli olduğu ve olumlu deneyimlerin olumsuz görüşleri tersine çevirdiğini ortaya koymuşlardır. Ayrıca ağızda ağıza iletişimde önemli olan alıcı değil iletişimi başlatan kişi olduğunu tespit edilmiştir.

Halstead (2002) yaptığı çalışma sonucunda, olumsuz ağızdan ağıza yapılan tüketici şikâyetleri ve memnuniyetsizliklerini üçüncü kişilerle paylaşıp paylaşmadığını ve deneyimlerle yeniden satın alma kararlarını etkileyip etkilemediğini araştırmıştır. Araştırma sonucuna göre, tatmin olmamış tüketiciler, tatmin olan müşterilerden daha fazla olumsuz ağızdan ağıza şikâyet ile ilgilendikleri ve daha fazla kişiye bu tatminsizliklerini aktardıklarını tespit etmişlerdir. Olumsuz ağızdan ağıza şikâyet tüketicilerin tercihlerini etkilediğinde işletmeyi de olumsuz etkilediğinden işletmelerin daha dikkatli olması gerektiğini vurgulamıştır. Coombs ve Holladay (2007) yaptıkları çalışmada, öfkeli arabulucunun, satın alma niyeti ve kriz yönetimi arasında ilişkiye etkisinin olup olmadığını araştırmışlardır. Tüketicilerin tatminsizlik düzeyi olumsuz ağızdan ağıza şikâyeti etkilediği, tüketicilerin kasıtlı yapılan hatalardan dolayı olumsuz ağızdan ağıza şikâyete geçtiklerini ortaya koymuşlardır. İşletmelerin oluşan olumsuz ağızdan ağıza şikâyet oluşmaması için çaba sarf etmesi gerektiğini belirtmişlerdir.

Solvang (2008), mağazalarda yaptığı bir araştırmada, 400 kişiye anket uygulamıştır. Analiz sonucuna göre, ağızdan avğıza şikâyetin memnuniyet ve sadakati etkilediğini belirtmiştir. Eğer şikâyetler iyi yönetilirse olumsuz ağızdan ağıza şikâyetin azalacağını tespit etmiştir. 
Karaoğlu (2010) yaptığı çalışmada, ağızdan ağıza şikâyetin müşteri satın alma kararlarına etkisi olup olmadığını araştırmıştır. 141 cevaplayıcı ile yapılan anket sonucuna göre, müşterilerin mal veya hizmeti satın alırken ağızdan ağıza şikâyetten fazlasıyla etkilendiğini belirtmiştir. Kutluk ve Avcıkurt (2014), ağızdan ağıza şikâyet ve seyahat acentelerinin müşterileri üzerindeki etkisinin olup olmadığı araştırmışlardır. İstanbulKadıköy bölgesinde faaliyet gösteren acentelerde tek aşamalı alan örnekleme yöntemi ile 390 müşteriye ulaşılmıştır. Araştırmaya göre, ağızdan ağıza şikâyet, en fazla iş arkadaşları arasında yapıldığı, tercih edilen en güvenilir tavsiye kaynağı olduğu ve ağızdan ağıza şikâyetin yayılmasında cinsiyet farklılığının olmadığı sonucuna ulaşılmıştır.

\section{Yöntem}

$\mathrm{Bu}$ çalışmanın amacı, cevaplayıcıların demografik özellikleri ile olumlu ve olumsuz ağızdan ağıza yapılan şikâyetler ve şikâyet sonrası oluşan müşteri tatmini arasında farklılıklar olup olmadığını ve şikâyetleri ele alış şekillerini öğrenmektir. Tüketicilerin müşteri şikâyetleri baz alınarak olumlu ağızdan ağıza şikâyet, olumsuz ağızdan ağıza şikâyet ve şikâyet sonrası oluşan müşteri tatmininin işletmeyi gelecekte nasıl etkileyeceği ve işletmeye yol gösterici olması açısından önemlidir. Çalışmada örneklem olarak Bolu il merkezinde faaliyet gösteren bir otomobil bayi yetkili servisinden mal veya hizmet almış müşteriler oluşturmaktadır. Araştırma, tesadüfi olmayan kolayda örnekleme yöntemi ile 447 kişiye yüz yüze anket çalışması yapılmıştır. Elde edilen anketlerden geçersiz olduğu tespit edilenlerin ayrılmasından sonra 405 cevaplayıcının anketi değerlendirmeye alınmıştır. Ankete katılanların ifadelere katılma derecesini ölçmek için 5'li Likert Ölçeği kullanılmıştır.

Anket formu, 47 sorudan oluşmaktadır. Soruların ilk bölümü cevaplayıcıların demografik bilgileri, yetkili servise giren aracın türü, yaş1, yetkili serviste oluşan şikâyet nedenleri, oluşan şikâyetlerin hangi kanal aracılığıyla paylaşıldığı, şikâyetin nasıl sonuçlandığı, cevaplayıcıların şikâyetlerini çevresine anlatıp anlatmadığını belirlemeye yönelik çoktan seçmeli sorular bulunmaktadır. Anketin ikinci bölümünde; olumlu ve olumsuz ağıdan ağıza yapılan müşteri şikâyetleri ve şikâyet sonrası oluşan müşteri tatmini ölçmeye yönelik sorular yer almaktadır. Araştırmada kullanılan ölçekler Tablo 1'de gösterilmektedir.

Tablo 1: Modelde Yer Alan Ölçekler

\begin{tabular}{|l|l|c|}
\hline Değişken & Kaynak & $\begin{array}{c}\text { İfade } \\
\text { Sayısı }\end{array}$ \\
\hline Olumlu Ağızdan Ağıza Şikâyet & Davidow, 2003 & 4 ifade \\
\hline
\end{tabular}




\begin{tabular}{|l|l|l|}
\hline Olumsuz Ağızdan Ağıza Şikâyet & $\begin{array}{l}\text { Goyette, Ricard, Bergeron, ve } \\
\text { Marticotte, 2010 }\end{array}$ & 2 ifade \\
\hline Şikâyet Sonrası Oluşan Müşteri Tatmini & Weun, Beatty ve Jones, 2004 & 5 ifade \\
\hline
\end{tabular}

Araştırmanın alt amaçları aşağıdaki gibi özetlenebilir:

- Satış sonrası hizmet veren işletmedeki cevaplayıcıların demografik özelliklerinin incelenmesi,

- Satış sonrası oluşan şikâyetlerin nedenlerinin belirlenmesi,

- Cevaplayıcıların şikâyetlerini işletmeye hangi kanal aracılığıyla paylaştığının belirlenmesi,

- İşletmeye bildirilen şikâyetlerin nasıl sonuçlandığının tespit edilmesi,

- Oluşan şikâyeti akraba ve/veya çevresine anlatıp anlatmadığı eğer anlattıysa da yaklaşık kaç kişiye anlattığının belirlenmesi,

- Cevaplayıcıların demografik özellikleri ile olumlu ve olumsuz ağızdan ağıza şikâyet ve şikâyet sonrası oluşan müşteri tatmini puanları bakımından istatistiksel anlamlı farklilık bulunup bulunmadığının belirlenmesi,

- Müşteri şikâyetler nedenleri ile olumlu ve olumsuz ağızdan ağıza şikâyet ve şikâyet sonrası oluşan müşteri tatmini puanları bakımından istatistiksel anlamlı farklılık bulunup bulunmadığının belirlenmesidir.

Müşteri şikâyetler nedenleri ile demografik özelliklerin olumlu ve olumsuz ağızdan ağıza şikâyetler ve şikâyet sonrası oluşan müşteri tatmini açısından ele alınarak incelemeye çalışıldığ Şekil 1'de gösterilmektedir.

Şekil 1: Araştırma Modeli

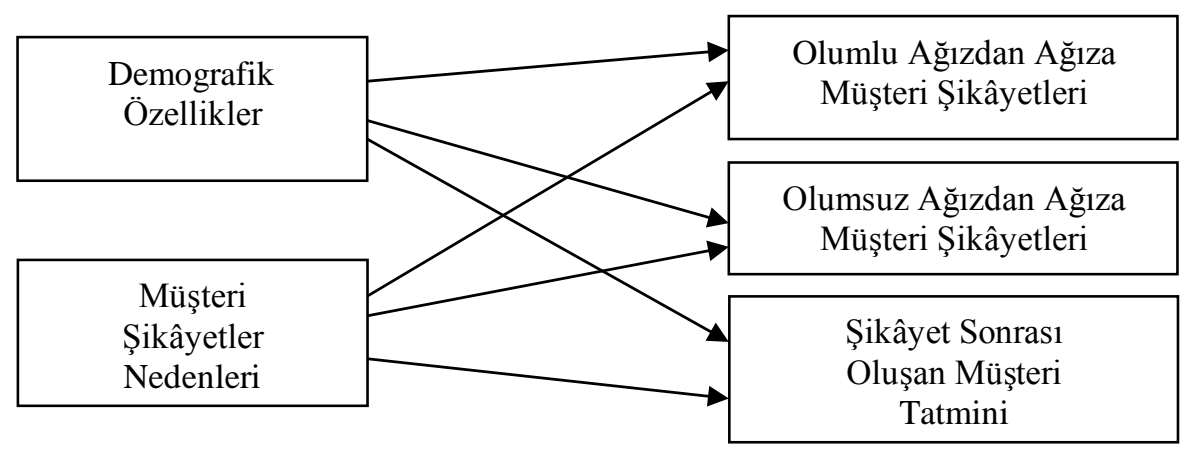

Çalışmadan elde edilen veriler SPSS programı vasıtasıyla analiz edilmiştir. Verilerin analizi SPSS programı ile yapılmış ve $\% 95$ güven düzeyi ile çalışılmıştır. Çalışmaya katılan kişilerin demografik özellikleri 726 
ve şikâyet süreci ile ilgili bilgileri görmek için frekans analizi yapılmıştır. Ölçek maddelerinin geçerlilik ve güvenilirliği faktör analizi ve güvenilirlik analizi ile demografik değişkenlere ve şikâyet nedenlere göre farklılık gösterme durumu Mann Whitney ve Kruskal Wallis testleri ile analiz edilmiştir.

\section{Bulgular}

\subsection{Demografik Özellikleri}

Cevaplayıcıların demografik özellikleri kısmında cinsiyet, yaş, medeni durum, aylık gelir durumu, eğitim durumu, meslek ayrıca yetkili servise getirilen aracın türü ve yaşı açısından incelenip frekans analizi yapılarak aşağıdaki tablolar elde edilmiştir.

Tablo 2: Demografik Değişkenlere Ait Frekans Tablosu

\begin{tabular}{|c|c|c|c|c|c|}
\hline Değișkenler & $\mathbf{n}$ & $\%$ & Değișkenler & $\mathbf{n}$ & $\%$ \\
\hline \multicolumn{3}{|l|}{ Cinsiyet } & \multicolumn{3}{|l|}{ Ĕgitim } \\
\hline Kadın & 73 & 18,0 & İlköğretim & 28 & 6,9 \\
\hline Erkek & 332 & 82,0 & Ortaokul & 38 & 9,3 \\
\hline & $\mathbf{N}$ & $\%$ & Lise & 125 & 30,9 \\
\hline \multicolumn{3}{|l|}{ Yaş } & Ön lisans & 42 & 10,4 \\
\hline 30 yaş ve altı & 92 & 22,7 & Lisans & 129 & 31,9 \\
\hline $31-40$ & 127 & 31,4 & Lisansüstü & 43 & 10,6 \\
\hline $41-50$ & 130 & 32,1 & & $\mathbf{n}$ & $\%$ \\
\hline 51 yaş ve üzeri & 56 & 13,8 & \multicolumn{3}{|l|}{ Meslek } \\
\hline & $\mathbf{N}$ & $\%$ & Memur & 130 & 32,0 \\
\hline \multicolumn{3}{|l|}{ Medeni Durum } & İşçi & 106 & 26,2 \\
\hline Evli & 298 & 73,6 & Serbest Meslek & 96 & 23,7 \\
\hline Bekâr & 107 & 26,4 & Ev Hanımı & 16 & 4,0 \\
\hline & $\mathbf{N}$ & $\%$ & Öğrenci & 12 & 3,0 \\
\hline Gelir & & & Diğer & 45 & 11,1 \\
\hline 3000 TL ve alt1 & 207 & 51,1 & \multicolumn{3}{|c|}{ n } \\
\hline $3001-5000 \mathrm{TL}$ & 133 & 32,8 & \multicolumn{3}{|l|}{ Araç Türü } \\
\hline \multirow[t]{2}{*}{5001 TL ve üstü } & 65 & 16,1 & Otomobil & 270 & 66,7 \\
\hline & $\mathbf{N}$ & $\%$ & Ticari & 135 & 33,3 \\
\hline \multicolumn{3}{|l|}{ Meslek } & \multicolumn{2}{|c|}{ n } & $\%$ \\
\hline Memur & 130 & 32,0 & \multicolumn{3}{|l|}{ Araç Yaşı } \\
\hline İşçi & 106 & 26,2 & $1-3$ & 222 & 54,8 \\
\hline Serbest Meslek & 96 & 23,7 & $4-7$ & 126 & 31,1 \\
\hline Ev Hanımı & 16 & 4,0 & 8 ve üstü & 57 & 14,1 \\
\hline Öğrenci & 12 & 3,0 & & & \\
\hline Diğer & 45 & 11,1 & & & \\
\hline
\end{tabular}


Tablo 3: Müşteri Şikâyet Nedenlerinin Dağılımı

\begin{tabular}{|l|c|c|c|c|c|c|}
\hline Şikâyet Nedenleri & \multicolumn{2}{|c|}{$\begin{array}{c}\text { Şikâyetim } \\
\text { Var }\end{array}$} & \multicolumn{2}{c|}{$\begin{array}{c}\text { Şikâyetim } \\
\text { Yok }\end{array}$} & \multicolumn{2}{l|}{ Toplam } \\
\hline & $\mathbf{n}$ & $\mathbf{\%}$ & $\mathbf{n}$ & $\mathbf{\%}$ & $\mathbf{n}$ & $\mathbf{\%}$ \\
\hline $\begin{array}{l}\text { Yetkili servise ulaşım güçlüğü (telefon / } \\
\text { lokasyon) }\end{array}$ & 95 & 23,5 & 310 & 76,5 & 405 & 100 \\
\hline Lavabo ve tuvaletlerin temiz olmaması & 35 & 8,6 & 370 & 91,4 & 405 & 100 \\
\hline Yedek parça bulunurluğu & 69 & 17,0 & 336 & 83,0 & 405 & 100 \\
\hline $\begin{array}{l}\text { Servise giren aracın zamanında teslim } \\
\text { edilmemesi }\end{array}$ & 97 & 24,0 & 308 & 76,0 & 405 & 100 \\
\hline Yetkili servisin fiziki görünümü & 28 & 6,9 & 377 & 93,1 & 405 & 100 \\
\hline Alternatif ulaşım sağlanmaması & 67 & 16,5 & 338 & 83,5 & 405 & 100 \\
\hline $\begin{array}{l}\text { Tanıtımlarda belirtilen ile sunulanın } \\
\text { aynı olmaması }\end{array}$ & 35 & 8,6 & 370 & 91,4 & 405 & 100 \\
\hline $\begin{array}{l}\text { Araç teslim edildiğindeki iç ve diş } \\
\text { temizliği }\end{array}$ & 44 & 10,9 & 361 & 89,1 & 405 & 100 \\
\hline Randevuya saatlerine uyulmaması & 65 & 16,0 & 340 & 84,0 & 405 & 100 \\
\hline Bekleme salonu / ikram yetersizliği & 56 & 13,8 & 349 & 86,2 & 405 & 100 \\
\hline Çalışanın ilgisiz olması & 66 & 16,3 & 339 & 83,7 & 405 & 100 \\
\hline Aynı sorunun devam etmesi & 46 & 11,4 & 359 & 88,6 & 405 & 100 \\
\hline Verilen fiyata uyulmaması & 28 & 6,9 & 377 & 93,1 & 405 & 100 \\
\hline Bilgilendirme yetersizliği & 76 & 18,8 & 329 & 81,2 & 405 & 100 \\
\hline Fiyatların yüksek olması & 249 & 61,5 & 156 & 38,5 & 405 & 100 \\
\hline
\end{tabular}

Müşteri şikâyetlerine göre bakıldığında, cevaplayıcıların çoğunluğu söz konusu sorunların genelinde şikâyeti olmamakla birlikte en fazla şikâyetçi olunan dört konu; fiyatların yüksek olması $(\% 61,5)$, servise giren aracın zamanında teslim edilmemesi $(\% 24,0)$, yetkili servise ulaşım güçlüğü(\%23,5), bilgilendirme yetersizliği $(\% 18,8)$ olarak görülmektedir.

Cevaplayıcıların şikâyetleri paylaştıkları kanallar hangileri kullandıklarını önem derecesine göre bakıldığında, cevaplayıcıların ilk üç tercihi içinde ele aldığı şikâyet kanalı olarak; çoğunluğu şikâyetlerini yetkili çalışan ile yüz yüze/telefonla paylaştığını $(\% 92,6)$ belirtmektedir. Bunu \%30,1 ile yaşadığı sorunu genel müdürlük/merkez ile paylaşanlar izlemektedir. Cevaplayıcıların \%24,7 'si ise internet şikâyet siteleri ve forumlara yazarak sorununu dile getirdiklerini ifade etmektedirler. Ancak şikâyetini paylaşmayanlar daha radikal karar almakta ve yasal yollara başvurma, işletmenin internet sitesini mail olarak yazma ve sosyal medyada paylaşma daha çok kullanılmaktadır.

Şikâyetlerden sonuç alma durumuna bakıldığında, cevaplayıcıların çoğunluğu \%48,1 şikâyetine yanıt aldığını ancak tatmin edici olmadığını, \%30,6's1 şikâyetine yanıt aldığını ve sorunun çözüldüğünü, \%11,4' ü 
yanıt alamadığını ve sorunun hala çözülmediğini, yani \%48,1 ve \%11,4 ile sorunların tatmin edici sonuca ulaşamadıkları görülmektedir.

Son olarak cevaplayıcıların şikâyeti çevresine anlatma ve anlattığı kişi sayısına bakıldığında, cevaplayıcıların çoğunluğu işletmede yaşadığı sorunları ve şikâyetlerini yakın çevresine anlatmakta $(\% 75,6)$ ve ortalama 10 ve üstü kişiye anlattığ $1(\% 43,5)$ görülmektedir.

\subsection{Faktör Analizleri ve Güvenirlikleri}

Olumlu ağızdan ağıza şikâyet, olumsuz ağızdan ağıza şikâyet ve şikâyet sonrası oluşan müşteri tatmini ölçeklerin faktör analizine uygunluğunun belirlenmesi amacıyla yapılan KMO ve Bartlett testi sonuçları Tablo 4'te verilmiştir.

Tablo 4: KMO ve Barlett's Testi

\begin{tabular}{|l|c|c|}
\hline FAKTÖR & KMO & P \\
\hline Olumlu Ağızdan Ağıza Şikâyet & 0,816 & 0,000 \\
\hline Olumsuz Ağızdan Ağıza Şikâyet & 0,501 & 0,000 \\
\hline Şikâyet Sonrası Oluşan Müşteri Tatmini & 0,634 & 0,000 \\
\hline
\end{tabular}

Ölçeklerin faktör analizine uygunluğunun belirlenmesi amacıyla yapılan KMO ve Bartlett testi sonuçları tabloda verilmiştir. Analiz sonucuna göre KMO değerleri 0,500'den büyük ve Bartlett $X^{2}$ testi anlamlı bulunmuştur $(\mathrm{p}<0,05)$. Buna göre ölçekler faktör analizine uygundur. Aşağıda ölçek maddelerine ilişkin faktör dağılımları ve güvenilirlik analizi sonuçları görülmektedir.

Tablo 5: Olumlu Ağızdan Ağıza Şikâyet Ölçeğinin Faktör Dağılımları ve Güvenilirlik Analizi Sonuçları

\begin{tabular}{|c|c|c|c|c|}
\hline Faktör & Madde & $\begin{array}{l}\text { Faktör } \\
\text { Yükü }\end{array}$ & $\begin{array}{c}\text { Açıllanan } \\
\text { Varyans } \\
\text { Oranı }\end{array}$ & $\begin{array}{l}\text { Cronbach's } \\
\text { Alfa }\end{array}$ \\
\hline \multirow{4}{*}{$\begin{array}{l}\text { Olumlu } \\
\text { Ağızdan } \\
\text { AğgIza } \\
\text { Şikâyet }\end{array}$} & $\begin{array}{l}\text { Her firsatta başkalarına şikâyet } \\
\text { deneyimimden bahsederim. }\end{array}$ & 0,891 & \multirow{4}{*}{31,818} & \multirow{4}{*}{0,881} \\
\hline & $\begin{array}{l}\text { Çevremdeki herhangi biri beni } \\
\text { dinleyeceği } \text { zaman şikâyet } \\
\text { deneyimim hakkında konuşurum. }\end{array}$ & 0,886 & & \\
\hline & $\begin{array}{l}\text { Şikâyet deneyimlerim hakkında } \\
\text { konuştuğum zaman, yetkili servis } \\
\text { tarafından nasıl kötü bir şekilde } \\
\text { ele alındığını insanlara bildiririm. }\end{array}$ & 0,870 & & \\
\hline & $\begin{array}{l}\text { Yetkili serviste oluşan şikâyetimi } \\
\text { mümkün olduğunca çok kişiyle } \\
\text { paylaşirım. }\end{array}$ & 0,785 & & \\
\hline
\end{tabular}


Olumlu Ağızdan Ağıza Şikâyet faktör yükleri 0,891 ile 0,785 arasında değişen 4 maddeden oluşmaktadır. Faktörün toplam varyansı açıklama oran1 \%31,818 ve güvenirlik katsayıs1 0,881 'dir. Buna göre faktörün güvenirlik düzeyi çok yüksektir.

Tablo 6: Olumsuz Ağızdan Ağıza Şikâyet Ölçeğinin Faktör Dağılımları ve Güvenilirlik Analizi Sonuçları

\begin{tabular}{|c|c|c|c|c|}
\hline Faktör & Madde & $\begin{array}{c}\text { Faktör } \\
\text { Yükü }\end{array}$ & $\begin{array}{l}\text { Açılananan } \\
\text { Varyans } \\
\text { Oranı }\end{array}$ & $\begin{array}{c}\text { Cronbach's } \\
\text { Alfa }\end{array}$ \\
\hline \multirow{2}{*}{$\begin{array}{l}\text { Olumsuz } \\
\text { Ağızdan } \\
\text { Ağıza } \\
\text { Şikâyet }\end{array}$} & $\begin{array}{lr}\text { Yetkili } & \text { servisi } \\
\text { yaşadığıkım } & \text { sorunlardan } \\
\text { dolayı } & \text { başkalarına } \\
\text { olumsuz şeyler söylerim. }\end{array}$ & 0,921 & \multirow{2}{*}{46,889} & \multirow{2}{*}{0,822} \\
\hline & $\begin{array}{l}\text { Başkalariyla bu yetkili } \\
\text { servis hakkında kötü } \\
\text { konuşurum. }\end{array}$ & 0,921 & & \\
\hline
\end{tabular}

Olumsuz Ağızdan Ağıza İletişim faktör yükleri 0,921 olan 2 maddeden oluşmaktadır. Faktörün toplam varyansı açıklama oranı \%46,889 ve güvenirlik katsayısı 0,822 'dir. Buna göre faktörün güvenirlik düzeyi çok yüksektir.

Tablo 7: Şikâyet Sonrası Oluşan Müşteri Tatmini Ölçeğinin Faktör

Dağılımları ve Güvenilirlik Analizi Sonuçları

\begin{tabular}{|c|c|c|c|c|}
\hline Faktör & Madde & $\begin{array}{c}\text { Faktör } \\
\text { Yükü }\end{array}$ & $\begin{array}{c}\text { Açıklanan } \\
\text { Varyans } \\
\text { Oranı } \\
\end{array}$ & $\begin{array}{c}\text { Cronbach's } \\
\text { Alfa }\end{array}$ \\
\hline \multirow{4}{*}{$\begin{array}{l}\text { Şikâyet } \\
\text { Sonrası } \\
\text { Oluşan } \\
\text { Müşteri } \\
\text { Tatmini }\end{array}$} & $\begin{array}{l}\text { Şikâyet sürecini genel olarak } \\
\text { değerlendirdiğimde şikâyetimin } \\
\text { çözülme şeklinden tatmin } \\
\text { oldum. }\end{array}$ & 0,891 & \multirow{4}{*}{45,395} & \multirow{4}{*}{0,778} \\
\hline & $\begin{array}{l}\text { Şikâyet sürecini genel olarak } \\
\text { değerlendirdiğimde yaşadığım } \\
\text { deneyimden memnun kaldım. }\end{array}$ & 0,875 & & \\
\hline & $\begin{array}{l}\text { Şikâyet sürecini genel olarak } \\
\text { değerlendirdiğimde şikâyetime } \\
\text { verilen cevabın yeterli } \\
\text { olduğunu düşünüyorum. }\end{array}$ & 0,793 & & \\
\hline & $\begin{array}{lr}\text { Şikâyet sürecini genel olarak } \\
\text { değerlendirdiğimde } & \text { yetkili } \\
\text { servisin gösterdiği } & \text { çabadan }\end{array}$ & 0,817 & & \\
\hline
\end{tabular}




\begin{tabular}{|l|l|l|l|}
\hline memnun kalmadım. & & \multirow{3}{*}{} \\
\cline { 1 - 3 } $\begin{array}{l}\text { Şikâyet sürecini genel olarak } \\
\text { değerlendirdiğimde sorunumun } \\
\text { ele alınış şeklinden mutlu } \\
\text { değilim. }\end{array}$ & 0,740 & & \\
\hline
\end{tabular}

Şikâyet Sonrası Oluşan Müşteri Tatmini faktör yükleri 0,891 ile 0,74 arasında değişen 5 maddeden oluşmaktadır. Faktörün toplam varyansı açıklama oranı \% 45,395 ve güvenirlik katsayısı 0,778'dir. Buna göre faktörün güvenirlik düzeyi yüksektir.

Tablo 8: Ölçek Puanların Normallik Testi

\begin{tabular}{|l|c|c|}
\hline $\mathbf{n = 4 0 5}$ & İstatistik & P \\
\hline Olumlu Ağızdan Ağıza Şikâyet &, 122 &, 000 \\
\hline Olumsuz Ağızdan Ağıza Şikâyet &, 137 &, 000 \\
\hline Şikâyet Sonrası Oluşan Müşteri Tatmini &, 070 &, 001 \\
\hline
\end{tabular}

Ölçek puanlarının normalliği için yapılan Kolmogrov-Smirnov normallik testi sonuçlarına göre; ölçek puanlarının normal dağılım göstermediklerinden dolayı karşıllaştırma analizlerinde parametrik olmayan testler kullanılmıştır $(p<0,05)$.

\subsection{Karşılaştırma Analizleri}

Ölçek maddelerinin demografik değişkenlere ve müşteri şikâyet nedenlerine göre farklılık gösterme durumu bağımsız iki grubun karşılaştırılması için kullanılan Mann Whitney, üç veya daha fazla sayıda grubun karşılaştırılması için Kruskal Wallis testleri ile analiz edilmiştir. Cevaplayıcıların demografik özellikleri ve müşteri şikâyetleri ile ilgili ağızdan ağıza şikâyet ölçeğinin puanları bakımından karşılaştırma testi sonuçları Tablo 9'da gösterilmektedir.

Tablo 9: Demografik Özellikler ve Olumlu Ağızdan Ağıza Yapılan Müşteri Şikâyetlerinin Karşıllaştırılması

\begin{tabular}{|c|c|c|c|c|c|}
\hline \multicolumn{6}{|c|}{ Olumlu Ağızdan Ağıza Yapılan Müşteri Şikâyetleri } \\
\hline \multicolumn{3}{|c|}{$\mathbf{N}$} & $\begin{array}{c}\text { Sira } \\
\text { ortalama }\end{array}$ & $\mathbf{U}$ & $\mathbf{P}$ \\
\hline \multirow{2}{*}{ Cinsiyet } & Kadın & 73 & 229,44 & \multirow{2}{*}{10188,0} & \multirow{2}{*}{$\mathbf{0 , 0 3 3} *$} \\
\hline & Erkek & 332 & 197,19 & & \\
\hline \multirow{4}{*}{ Yaş } & 30 yaş ve alt1 & 92 & 175,48 & \multirow{4}{*}{15,957} & \multirow{4}{*}{$\mathbf{0 , 0 0 1 *}$} \\
\hline & $31-40$ & 127 & 220,00 & & \\
\hline & $41-50$ & 130 & 220,99 & & \\
\hline & 51yaş ve üzeri & 56 & 167,90 & & \\
\hline \multirow{2}{*}{$\begin{array}{l}\text { Gelir } \\
\text { Grupları }\end{array}$} & 3000 TL ve alt1 & 207 & 186,98 & \multirow{2}{*}{7,986} & \multirow{2}{*}{$\mathbf{0 , 0 1 8 *}$} \\
\hline & $3001-5000 \mathrm{TL}$ & 133 & 219,04 & & \\
\hline
\end{tabular}




\begin{tabular}{|c|c|c|c|c|c|}
\hline & 5001 TL ve üstü & 65 & 221,19 & & \\
\hline \multirow{6}{*}{$\begin{array}{l}\text { Eğitim } \\
\text { Durumu }\end{array}$} & İlköğretim & 28 & 140,29 & \multirow{6}{*}{24,389} & \multirow{6}{*}{$0,000 *$} \\
\hline & Ortaokul & 38 & 219,83 & & \\
\hline & Lise & 125 & 178,13 & & \\
\hline & Önlisans & 42 & 186,58 & & \\
\hline & Lisans & 129 & 230,04 & & \\
\hline & Lisansüstü & 43 & 228,07 & & \\
\hline \multirow{6}{*}{$\begin{array}{l}\text { Meslek } \\
\text { Durumu }\end{array}$} & Memur & 130 & 224,96 & \multirow{6}{*}{15,749} & \multirow{6}{*}{$0,008 *$} \\
\hline & İşçi & 106 & 174,82 & & \\
\hline & Serbest Meslek & 96 & 197,70 & & \\
\hline & Ev Hanımı & 16 & 138,81 & & \\
\hline & Öğrenci & 12 & 215,71 & & \\
\hline & Diğer & 45 & 201,47 & & \\
\hline
\end{tabular}

$*_{\mathrm{p}}<0,05$ anlamlı fark var, $\mathrm{p}>0,05$ anlamlı fark yok

Cinsiyet için yapılan test sonucuna göre; kadınlar ve erkekler arasında olumlu ağızdan ağıza şikâyet puanı bakımından istatistiksel anlamlı farklılık bulunmaktadır. Buna göre kadınların müşteri şikâyetleri ile ilgili olumlu ağızdan ağıza şikâyet puanı daha yüksektir.

Yaş grupları için yapılan test sonucuna göre; yaş grupları arasında olumlu ağızdan ağıza şikâyet puanı bakımından istatistiksel anlamlı farklılık bulunmaktadır. Buna göre 51 yaş ve üzerindekilerin olumlu ağızdan ağıza şikâyet tutumu en düşük iken 41-50 yaşındakilerin en yüksektir.

Toplam aylık gelir grupları için yapılan test sonucuna göre; toplam aylık gelir grupları arasında olumlu ağızdan ağıza şikâyet puanı bakımından istatistiksel anlamlı farklılık bulunmaktadır. Buna göre 3000 TL ve altı geliri olanların olumlu ağızdan ağıza şikâyet tutumu en düşük iken 5001 TL ve üstü geliri olanların en yüksektir.

Eğitim durumu grupları için yapılan test sonucuna göre; eğitim durumu grupları arasında ağızdan ağıza şikâyet puanı bakımından istatistiksel anlamlı farklılık bulunmaktadır. Buna göre ilköğretim mezunlarının olumlu ağızdan ağıza şikâyet tutumu en düşük iken lisans mezunlarının en yüksektir.

Meslek grupları için yapılan test sonucuna göre; meslek grupları arasında olumlu ağızdan ağıza şikâyet puanı bakımından istatistiksel anlamlı farklılık bulunmaktadır. Buna göre ev hanımlarının olumlu ağızdan ağıza şikâyet tutumu en düşük iken memurların en yüksektir.

Cevaplayıcıların demografik özellikleri ve olumsuz ağızdan ağıza müşteri şikâyet ölçeğinin puanları bakımından karşılaştırma testi sonuçları Tablo 10'da gösterilmektedir. 
Tablo 10: Demografik Özellikler ile Olumsuz Ağızdan Ağıza Yapılan Müşteri Şikâyetleri Karşılaştırılması

\begin{tabular}{|c|c|c|c|c|c|}
\hline \multicolumn{6}{|c|}{ Olumsuz Ă̆ızdan Ağıza Yapılan Müşteri Şikâyetleri } \\
\hline \multicolumn{3}{|l|}{$\mathbf{N}$} & Sura Ortalama & $\mathbf{U}$ & $\mathbf{P}$ \\
\hline \multirow{4}{*}{ Yaş } & 30 yaş ve altı & 92 & 186,47 & \multirow{4}{*}{8,617} & \multirow{4}{*}{$\mathbf{0 , 0 3 5 *}$} \\
\hline & $31-40$ & 127 & 221,52 & & \\
\hline & $41-50$ & 130 & 208,52 & & \\
\hline & 51yaş ve üzeri & 56 & 175,35 & & \\
\hline \multirow{6}{*}{$\begin{array}{l}\text { Eğitim } \\
\text { Durumu }\end{array}$} & İlköğretim & 28 & 138,18 & \multirow{6}{*}{23,667} & \multirow{6}{*}{$0,000 *$} \\
\hline & Ortaokul & 38 & 239,97 & & \\
\hline & Lise & 125 & 178,26 & & \\
\hline & Ön lisans & 42 & 196,60 & & \\
\hline & Lisans & 129 & 222,44 & & \\
\hline & Lisansüstü & 43 & 223,92 & & \\
\hline \multirow{6}{*}{$\begin{array}{l}\text { Meslek } \\
\text { Durumu }\end{array}$} & Memur & 130 & 220,11 & \multirow{6}{*}{18,518} & \multirow{6}{*}{$0,002 *$} \\
\hline & İşçi & 106 & 176,78 & & \\
\hline & Serbest meslek & 96 & 206,65 & & \\
\hline & Ev hanımı & 16 & 111,06 & & \\
\hline & Öğrenci & 12 & 210,08 & & \\
\hline & Diğer & 45 & 202,16 & & \\
\hline
\end{tabular}

${ }^{*} \mathrm{p}<0,05$ anlamlı fark var, $\mathrm{p}>0,05$ anlamlı fark yok

Yaş grupları için yapılan test sonucuna göre; yaş grupları arasında olumsuz ağızdan ağıza şikâyet puanı bakımından istatistiksel anlamlı farklılık bulunmaktadır. Buna göre 51 yaş ve üzerindekilerin olumsuz ağızdan ağıza şikâyet tutumu en düşük iken 31-40 yaşındakilerin en yüksektir.

Eğitim durumu grupları için yapılan test sonucuna göre; eğitim durumu grupları arasında olumsuz ağızdan ağıza şikâyet puanı bakımından istatistiksel anlamlı farklılık bulunmaktadır. Buna göre ilköğretim mezunlarının olumsuz ağızdan ağıza şikâyet tutumu en düşük iken ortaokul mezunlarının en yüksektir.

Meslek grupları için yapılan test sonucuna göre; meslek grupları arasında olumsuz ağızdan ağıza şikâyet puanı bakımından istatistiksel anlamlı farklılık bulunmaktadır. Buna göre ev hanımlarının olumsuz ağızdan ağıza şikâyet tutumu en düşük iken memurların en yüksektir.

Cevaplayıcıların demografik özellikleri ile şikâyet sonrası oluşan müşteri tatmini ölçeğinin puanları bakımından karşılaştırma testi sonuçları Tablo 11'de gösterilmektedir. 
Tablo 11: Demografik Özellikler ile Şikâyet Sonrası Oluşan Müşteri Tatmininin Karşılaştırılması

\begin{tabular}{|c|c|c|c|c|c|}
\hline \multicolumn{6}{|c|}{ Şikâyet Sonrası Oluşan Müşteri Tatmini } \\
\hline \multicolumn{3}{|c|}{$\mathbf{n}$} & $\begin{array}{c}\text { Sira } \\
\text { Ortalama }\end{array}$ & $\mathbf{U}$ & $\mathbf{P}$ \\
\hline \multirow{6}{*}{$\begin{array}{l}\text { Eğitim } \\
\text { Durumu }\end{array}$} & İlköğretim & 28 & 265,68 & \multirow{6}{*}{22,347} & \multirow{6}{*}{$0,000 *$} \\
\hline & Ortaokul & 38 & 149,29 & & \\
\hline & Lise & 125 & 205,89 & & \\
\hline & Ön lisans & 42 & 238,94 & & \\
\hline & Lisans & 129 & 188,47 & & \\
\hline & Lisansüstü & 43 & 199,69 & & \\
\hline
\end{tabular}

*p $<0,05$ anlamlı fark var, $\mathrm{p}>0,05$ anlamlı fark yok

Eğitim durumu grupları için yapılan test sonucuna göre eğitim durumu grupları arasında tatmin puanı bakımından istatistiksel anlamlı farklılık bulunmaktadır. Buna göre ortaokul mezunlarının şikâyet sonrası oluşan tatmin tutumu en düşük iken ilköğretim mezunlarının en yüksektir.

Cevaplayıcıların müşteri şikâyet nedenleri ile olumlu ağızdan ağıza şikâyet, olumsuz ağızdan ağıza şikâyet ve şikâyet sonrası oluşan müşteri tatmini ölçeğinin puanları bakımından karşılaştırma testi sonuçları Tablo 12'de gösterilmektedir.

Tablo 12: Şikâyet Nedenleri, Olumlu ve Olumsuz Ağızdan Yapılan Şikâyetler ve Şikâyet Sonrası Oluşan Müşteri Tatmini Ölçeğinin Karşılaştırılması

\begin{tabular}{|c|c|c|c|c|c|c|}
\hline \begin{tabular}{|l|} 
Şikâyet \\
Nedenleri
\end{tabular} & Ölçekler & & $\mathbf{n}$ & \begin{tabular}{|c|} 
Sira \\
Ortalama
\end{tabular} & $\mathbf{U}$ & $\mathbf{p}$ \\
\hline \multirow{2}{*}{$\begin{array}{l}\text { Servise giren } \\
\text { aracin } \\
\text { zamanında } \\
\text { teslim } \\
\text { edilmemesi } \\
\end{array}$} & \multirow{2}{*}{\begin{tabular}{|l|} 
Şikâyet \\
Sonrası \\
Oluşan \\
Müşteri \\
Tatmini \\
\end{tabular}} & $\begin{array}{l}\text { Şikâyetim } \\
\text { var }\end{array}$ & 97 & 170,14 & \multirow[b]{2}{*}{11750,5} & \multirow[b]{2}{*}{$0,001 *$} \\
\hline & & $\begin{array}{l}\text { Şikâyetim } \\
\text { yok }\end{array}$ & 308 & 213,35 & & \\
\hline \multirow{6}{*}{$\begin{array}{l}\text { Çalışanın } \\
\text { ilgisiz olması }\end{array}$} & $\begin{array}{l}\text { Olumlu } \\
\text { Ağızdan }\end{array}$ & $\begin{array}{l}\text { Şikâyetim } \\
\text { var }\end{array}$ & 66 & 256,51 & \multirow{2}{*}{7655,5} & \multirow{2}{*}{0,000 * } \\
\hline & $\begin{array}{l}\text { Ağıa } \\
\text { Şikâyet }\end{array}$ & $\begin{array}{l}\text { Şikâyetim } \\
\text { yok }\end{array}$ & 339 & 192,58 & & \\
\hline & $\begin{array}{l}\text { Olumsuz } \\
\text { Ağıdan }\end{array}$ & $\begin{array}{l}\text { Şikâyetim } \\
\text { var }\end{array}$ & 66 & 249,73 & \multirow{2}{*}{8102,5} & \multirow{2}{*}{$0,000 *$} \\
\hline & $\begin{array}{l}\text { A ğıza } \\
\text { Şikâyet }\end{array}$ & $\begin{array}{l}\text { Şikâyetim } \\
\text { yok }\end{array}$ & 339 & 193,90 & & \\
\hline & \begin{tabular}{|l|} 
Şikâyet \\
Sonrası
\end{tabular} & $\begin{array}{l}\text { Şikâyetim } \\
\text { var }\end{array}$ & 66 & 144,86 & \multirow{2}{*}{7350,0} & \multirow[t]{2}{*}{$0,000 *$} \\
\hline & Oluşan & Şikâyetim & 339 & 214,32 & & \\
\hline
\end{tabular}




\begin{tabular}{|c|c|c|c|c|c|c|}
\hline & $\begin{array}{l}\text { Müşteri } \\
\text { Tatmini }\end{array}$ & yok & & & & \\
\hline \multirow{2}{*}{$\begin{array}{l}\text { Ayni sorunun } \\
\text { devam etmesi }\end{array}$} & \multirow{2}{*}{$\begin{array}{l}\text { Şikâyet } \\
\text { Sonrası } \\
\text { Oluşan } \\
\text { Müşteri } \\
\text { Tatmini }\end{array}$} & $\begin{array}{l}\text { Şikâyetim } \\
\text { var }\end{array}$ & 46 & 143,04 & \multirow[b]{2}{*}{5499,0} & \multirow[b]{2}{*}{$0,000 *$} \\
\hline & & $\begin{array}{l}\text { Şikâyetim } \\
\text { yok }\end{array}$ & 359 & 210,68 & & \\
\hline \multirow{6}{*}{$\begin{array}{l}\text { Bilgilendirme } \\
\text { yetersizliği }\end{array}$} & \multirow{2}{*}{$\begin{array}{l}\text { Olumlu } \\
\text { A ğ1zdan } \\
\text { Ağ́za } \\
\text { yapılan } \\
\text { şikâyet }\end{array}$} & $\begin{array}{l}\text { Şikâyetim } \\
\text { var }\end{array}$ & 76 & 242,48 & \multirow[b]{2}{*}{9501,5} & \multirow[b]{2}{*}{$0,001 *$} \\
\hline & & $\begin{array}{l}\text { Şikâyetim } \\
\text { yok }\end{array}$ & 329 & 193,88 & & \\
\hline & \multirow{2}{*}{$\begin{array}{l}\text { Olumsuz } \\
\text { Ağıdan } \\
\text { Ağıza } \\
\text { yapılan } \\
\text { Şikâyet }\end{array}$} & \begin{tabular}{|l} 
Şikâyetim \\
var
\end{tabular} & 76 & 249,23 & \multirow[b]{2}{*}{8988,5} & \multirow[b]{2}{*}{$\mathbf{0 , 0 0 0 *}$} \\
\hline & & $\begin{array}{l}\text { Şikâyetim } \\
\text { yok }\end{array}$ & 329 & 192,32 & & \\
\hline & \multirow{2}{*}{$\begin{array}{l}\text { Şikâyet } \\
\text { Sonrası } \\
\text { Oluşan } \\
\text { Müşteri } \\
\text { Tatmini }\end{array}$} & \begin{tabular}{|l} 
Şikâyetim \\
var
\end{tabular} & 76 & 155,42 & \multirow[b]{2}{*}{8886,0} & \multirow[b]{2}{*}{$0,000 *$} \\
\hline & & $\begin{array}{l}\text { Şikâyetim } \\
\text { yok }\end{array}$ & 329 & 213,99 & & \\
\hline \multirow{6}{*}{$\begin{array}{l}\text { Fiyatların } \\
\text { yüksek } \\
\text { olması }\end{array}$} & $\begin{array}{l}\text { Olumlu } \\
\text { Ağızdan }\end{array}$ & $\begin{array}{l}\text { Şikâyetim } \\
\text { var }\end{array}$ & 249 & 185,40 & \multirow{2}{*}{15038,5} & \multirow{2}{*}{$0,000 *$} \\
\hline & $\begin{array}{l}\text { Ağıza } \\
\text { Șikâyet }\end{array}$ & \begin{tabular}{|l|}
$\begin{array}{l}\text { Şikâyetim } \\
\text { yok }\end{array}$ \\
\end{tabular} & 156 & 231,10 & & \\
\hline & $\begin{array}{l}\text { Olumsuz } \\
\text { Ağızdan }\end{array}$ & \begin{tabular}{|l} 
Şikâyetim \\
var
\end{tabular} & 249 & 188,42 & \multirow{2}{*}{15791,0} & \multirow{2}{*}{$0,001 *$} \\
\hline & $\begin{array}{l}\text { Ağıza } \\
\text { Şikâyet }\end{array}$ & \begin{tabular}{|l|}
$\begin{array}{l}\text { Şikâyetim } \\
\text { yok }\end{array}$ \\
\end{tabular} & 156 & 226,28 & & \\
\hline & \multirow{2}{*}{$\begin{array}{l}\text { Şikâyet } \\
\text { Sonrası } \\
\text { Oluşan } \\
\text { Müşteri } \\
\text { Tatmini }\end{array}$} & \begin{tabular}{|l} 
Şikâyetim \\
var
\end{tabular} & 249 & 223,96 & \multirow[b]{2}{*}{14203,5} & \multirow[b]{2}{*}{$0,000 *$} \\
\hline & & $\begin{array}{l}\text { Şikâyetim } \\
\text { yok }\end{array}$ & 156 & 169,55 & & \\
\hline
\end{tabular}

${ }^{*} \mathrm{p}<0,05$ anlamlı fark var, $\mathrm{p}>0,05$ anlamlı fark yok

Yapılan test sonucuna göre; servise giren aracın zamanında teslim edilmemesi ile ilgili şikâyeti olmayanlar şikâyeti olanlara göre şikâyet sonrası oluşan tatmin puanı bakımından istatistiksel anlamlı farklılık bulunmaktadır. Buna göre de servise giren aracın zamanında teslim edilmemesinden şikâyeti olmayanların şikâyet sonrası oluşan tatmin tutumu daha yüksektir.

Çalışanın ilgisiz olmasından şikâyeti olanlar ile olmayanlar arasında olumlu ağızdan ağıza şikâyet puanı bakımından istatistiksel anlamlı 
farklılık bulunmaktadır. Buna göre de çalışanın ilgisiz olmasından şikâyeti olanların olumlu ağızdan ağıza şikâyet tutumu daha yüksektir.

Çalışanın ilgisiz olmasından şikâyeti olanlar ile olmayanlar arasında olumsuz ağızdan ağıza şikâyet puanı bakımından istatistiksel anlamlı farklılık bulunmaktadır. Buna göre de çalışanın ilgisiz olmasından şikâyeti olanların olumsuz ağızdan ağıza şikâyet tutumu daha yüksektir.

Çalışanın ilgisiz olmasından şikâyeti olanlar ile olmayanlar arasında şikâyet sonrası oluşan tatmin puanı bakımından istatistiksel anlamlı farklılık bulunmaktadır. Buna göre de çalışanın ilgisiz olmasından şikâyeti olmayanların şikâyet sonrası oluşan müşteri tatmin tutumu daha yüksektir.

Aynı sorunun devam etmesinden şikâyeti olanlar ile olmayanlar arasında şikâyet sonrası oluşan tatmin puanı bakımından istatistiksel anlamlı farklılık bulunmaktadır. Buna göre aynı sorunun devam etmesinden şikâyeti olmayanların şikâyet sonrası oluşan müşteri tatmin düzeyi daha yüksektir.

Bilgilendirme yetersizliğinden şikâyeti olanlar ile olmayanlar arasında olumlu ağızdan ağıza şikâyet puanı bakımından istatistiksel anlamlı farklılık bulunmaktadır. Buna göre de bilgilendirme yetersizliğinden şikâyeti olanların olumlu ağızdan ağıza şikâyet tutumu daha yüksektir.

Bilgilendirme yetersizliğinden şikâyeti olanlar ile olmayanlar arasında olumsuz ağızdan ağıza şikâyet puanı bakımından istatistiksel anlamlı farklılık bulunmaktadır. Buna göre de bilgilendirme yetersizliğinden şikâyeti olanların olumsuz ağızdan ağıza şikâyet tutumu daha yüksektir.

Bilgilendirme yetersizliğinden şikâyeti olanlar ile olmayanlar arasında şikâyet sonrası oluşan tatmin puanı bakımından istatistiksel anlamlı farklılık bulunmaktadır. Buna göre de bilgilendirme yetersizliğinden şikâyeti olmayanların şikâyet sonrası oluşan müşteri tatmin düzeyi daha yüksektir.

Fiyatların yüksek olmasından şikâyeti olanlar ile olmayanlar arasında olumlu ağızdan ağıza puanı bakımından istatistiksel anlamlı farklılık bulunmaktadır. Buna göre de fiyatların yüksek olmasından şikâyeti olmayanların olumlu ağızdan ağıza şikâyet tutumu daha yüksektir.

Fiyatların yüksek olmasından şikâyeti olanlar ile olmayanlar arasında olumsuz ağızdan ağıza puanı bakımından istatistiksel anlamlı farklılık bulunmaktadır. Buna göre de fiyatların yüksek olmasından şikâyeti olmayanların olumsuz ağızdan ağıza şikâyet tutumu daha yüksektir. 
Fiyatların yüksek olmasından şikâyeti olanlar ile olmayanlar arasında şikâyet sonrası oluşan tatmin puanı bakımından istatistiksel anlamlı farklılık bulunmaktadır. Buna göre de fiyatların yüksek olmasından şikâyeti olanların şikâyet sonrası oluşan müşteri tatmin düzeyi daha yüksektir.

\section{Sonuç}

Müşterilerin işletmelerden satın aldıkları mal veya hizmetlerden memnun kalmadıklarında şikâyetlerini olumsuz ağızdan ağıza şikâyet yoluyla çevrelerine dile getirdikleri bilinmektedir. Olumsuz şikâyetler işletmenin müşterilerinin karar verme sürecinde de oldukça etkilidir ve işletmeye müşteri kaybına yol açabilir. İşletmelerin bu olumsuzluklarla karşılaşmaması için müşteri şikâyetlerinin hızlı bir şekilde ele alınıp çözülmesiyle müşteri memnuniyeti ve sadakati sağlama açısından önemlidir.

Analiz sonuçlarına göre, yetkili servis kullanan cevaplayıcıların demografik özelliklerine bakıldığında, cevaplayıcıların çoğunluğunun cinsiyeti erkek, 41-50 yaş arası, medeni durumu evli, eğitim durumu lisans ve 1001-3000 TL gelir düzeyine sahip olduğu görülmektedir. Şikâyetlerini bildiren cevaplayıcılar tarafından en fazla şikâyetçi olunan konu; servis fiyatlarının yüksek olduğu görülmektedir. Cevaplayıcıların şikâyetleri paylaştıkları kanallara bakıldığında, çoğunluğu şikâyetlerini yetkili çalışan ile yüz yüze/telefonla paylaştığını $(\% 92,6)$ belirtmektedir. Şikâyetlerden sonuç alma durumuna bakıldığında, cevaplayıcıların çoğunluğu $(\% 48,1)$ şikâyetine yanıt aldığını ancak tatmin edici olmadığı görülmektedir. Bu sonuç Phau ve Sari (2004)'nin buldukları sonuçlarla örtüşmektedir. Araştırmada katılımcıların \%75,6'sının işletmede yaşadıkları sorunları ve şikâyetlerini arkadaşlarına, ailesine ve çevrelerine olumsuz ağızdan ağıza şikâyet yoluyla ve ortalama 10 ve üstü kişiye anlattıkları görülmektedir. Bu sonuç Sujithamrak ve Lam (2005), Halstead (2002), Day ve London (1976)'nın buldukları sonuçlarla örtüşmektedir.

Cevaplayıcıların demografik özellikleri ve şikâyet nedenleri ile olumlu ve olumsuz ağızdan ağıza şikâyet ve şikâyet sonrası oluşan müşteri tatmini üzerinde anlamlı bir farklılık gösterip göstermediği incelendiğinde; demografik özellikler ile olumlu ve olumsuz ağızdan ağıza şikâyet ve şikâyet sonrası müşteri tatmini arasında istatistiksel olarak anlamlı bir farklılık vardır. Yaş değişkenine göre, 51 yaş ve üzerindekilerin olumsuz ağızdan ağıza şikâyet tutumu en düşük iken 31-40 yaşındakilerin en yüksektir. Eğitim değişkenine göre; ortaokul mezunu olan tüketicilerin olumsuz ağızdan ağıza şikâyet tutumu diğer eğitim gruplarına göre daha 
yüksektir. Bu sonuçlar Heung ve Lam (2003), Sujithamrak ve Lam (2005)'nn buldukları sonuçlarla farklılık göstermektedir. Bu grubun daha fazla olumsuz değerlendirme yaptığı görülmektedir. Meslek değişkenine göre; memur olan tüketicilerin olumsuz ağızdan ağıza şikâyet tutumu diğer meslek gruplarına göre daha yüksektir. Ayrıca fiyatların yüksek olmasından ve bilgilendirme yetersizliğinden şikâyeti olan cevaplayıcıların şikâyetlerle ilgili olumsuz ağızdan ağıza şikâyet tutumu daha yüksek olduğu belirlenmiştir.

İşletmelere öneriler ise, ağızdan ağıza şikâyetin ikna gücünün yüksek olması, olumsuz ağızdan ağıza şikâyetin satın alma kararlarından vazgeçirebileceği, işletme imajına zarar verebileceği, maddi kayıplar doğurabilme ihtimali dikkate alınarak yöneticilerin olumsuz ağızdan ağıza şikâyeti doğurabilecek her türlü durumu önceden görüp önlemeleri ve olumlu ağızdan ağıza şikâyet doğuracak ve geliştirecek ortamları yaratmaları gerekmektedir. Ayrıca yöneticilerin müşteri şikâyetlerine daha fazla önem vermeleri gerekmektedir. İşletmelerin, müşteriler için taleplerini aktarabileceği ve şikâyette bulunabileceği bir ortam sağlama yolunda çaba göstermesi gerekmektedir. Yetkili servisler ile ilgili en çok şikâyet edilen konuların başında fiyatların yüksek olması gelmektedir. İşletmeler mal veya hizmet fiyatlarını belirlerken ekonomik çevre koşulları dikkate alınarak müş̧eri tatmini sağlanmasına özen göstermelidir.

Bundan sonraki çalışmalar da, farklı hizmet sektörlerinde veya farklı endüstrilerde yapılacak araştırmalarda sektörel farklılıklara bakılabilir. $\mathrm{Bu}$ araştırma, Bolu il merkezinde faaliyet gösteren bir otomobil bayi yetkili servisinden mal veya hizmet almış ve şikâyeti olan müşteriler ile sinırlandırılmıştır.

\section{Kaynaklar}

Anderson, E. W. (1998), Customer Satisfaction and Word of Mouth, Journal of Service Research, 1(1), s.5-17.

Barış, G. (2008), Kusursuz Müşteri Memnuniyeti İçin Şikâyet Yönetimi, İstanbul: Mediacat Yayınları.

Barlow, J. ve Moller, C. (2009), Her Şikâyet Bir Armağandır (Çev. G. Bilgili), İstanbul: Rota Yayınları.

Bell, S. J. Mengüç, B. ve Stefani, S. L. (2004), When Customers Disappoint: A Model of Relational Internal Marketing and Customer Complaints, Journal of the Academy of Marketing Science, 32(2), s.112-126. 
Brouard, F. ve Larivet, S. (2010), Essay of Clarifications and Definitions of the Related Concepts of Social Enterprise, Social Entrepreneur and Social Entrepreneurship, Handbook of Research on Social Entrepreneurship, 18(7), s.537-551.

Coombs, T. W. ve Holladay, S. J. (2007), The Negative Communication Dynamic: Exploring the Impact of Stakeholder Affect on Behavioral Intentions, Journal of Communication Management, 11(4), s.300-312.

Davidow, M. (2003), Organizational Responses to Customer Complaints: What Works and What Doesn't. Journal of Service Research, 5(3), s.225-250.

Davidow, M. ve Dacin, P. A. (1997), Understanding and Influencing Consumer Complaint Behavior: Improving Organizational Complaint Management, NA-Advances in Consumer Research, 24, s.450-456.

Day, R. L. ve Landon, E. L. J. (1976), Collectıng Comprehensive Consumer Compliant Data by Survey Research, Advances in Consumer Research, 3(1), s.263-268.

Eşkinat, A. (2009), Müşterinin Elde Tutulmasında Şikâyet Yönetiminin Önemi ve Hizmet Sektörüne Illişkin Bir Uygulama. Yayımlanmamış Doktora Tezi, İstanbul: Marmara Üniversitesi Sosyal Bilimler Enstitüsü.

Gökdeniz, İ., Bozac1, İ. ve Karakaya, E. (2011), Şikâyet Yönetim Süreci Sonrası Memnuniyeti Etkileyen Faktörler Üzerine Uygulamalı Bir Araştırma, Selçuk Üniversitesi Sosyal Bilimler Enstitüsü Dergisi, 26, 173-185.

Goyette, I., Ricard, L., Bergeron, J. ve Marticotte, F. (2010), E-WOM Scale: Word-of-Mouth Measurement Scale for E-Services Context, Canadian Journal of Administrative Sciences/Revue Canadienne Des Sciences de l'Administration, 27(1), s.5-23.

Halstead, D. (2002), Negative Word of Mouth: Substitute for or Supplement to Consumer Complaints? Journal of Consumer Satisfaction, Dissatisfaction and Complaining Behavior, 15(1).

Harrison-Walker, J. L. (2001), E-Complaining: A Content Analysis of an Internet Complaint Forum, Journal of Services Marketing, 15(5), s.397-412.

Heung, V. C. ve Lam, T. (2003), Customer Complaint Behaviour 
Towards Hotel Restaurant Services, International Journal of Contemporary Hospitality Management, 15(5), s.283-289.

Karaca, Y. (2010), Ağızdan A ğıza Pazarlama, İstanbul: Beta Yayınları.

Karaoğlu, H. (2010), Ağızdan Ağıza İletişimin Tüketici Satın Alma Kararları Üzerine Etkisi ve Borusan Telekom Çalışanları Üzerinde Bir Araştırma, Yüksek Lisans Tezi, Kadir Has Üniversitesi Sosyal Bilimler Enstitüsü.

Kozak, M. (2006), Turizm Sektöründe Tüketicilerin Şikâyetlerini Bildirme Eğilimleri ve Çözümüne Yönelik Bireysel Önerileri Üzerine Bir Alan Araştırması, Muğla: Muğla Üniversitesi Yayınları.

Kutluk, A. ve Avcıkurt, C. (2014), Ağızdan Ağıza Pazarlamanın Müşterilerin Satın Alma Karar Süreçlerine Etkisi ve Bir Uygulama: İstanbul Seyahat Acenteleri Örneği, Journal of International Social Research, 7(29), s.613-622.

Lapré, M. A. ve Tsikriktsis, N. (2006), Organizational Learning Curves for Customer Dissatisfaction: Heterogeneity across Airlines, Management Science, 52(3), 352-366.

Manickas, P. A. ve Shea, L. J. (1997), Hotel Complaint Behavior and Resolution: A Content Analysis, Journal of Travel Research, 36(2), s.68-73.

Molinari, L. K., Abratt, R. ve Dion, P. (2008), Satisfaction, Quality and Value and Effects on Repurchase and Positive Word-of-Mouth Behavioral Intentions in A B2B Services Context, Journal of Services Marketing, 22(5), s.363-373.

Naylor, G. ve Kleiser, S. B. (2000), Negative Versus Positive Word-ofMouth: An Exception to the Rule, Journal of Consumer Satisfaction Dissatisfaction and Complaining Behavior, 13, s.2636.

Ngai, E. W., Heung, V. C., Wong, Y. H. ve Chan, F. K. (2007), Consumer Complaint Behavior of Asians and Non- Asians about Hotel Services: An Empirical Analysis, European Journal of Marketing, 41(11/12), s.1375-1391.

Olcay, A. ve Sürme, M. (2014), Otel İşletmelerinde Müşteri Şikâyetlerini Belirlemeye Yönelik Ampirik Bir Çalışma, Uluslararası Sosyal Araştırmalar Dergisi, 7(5), s.836-855.

Phau, I. ve Sari, R. P. (2004), Engaging in Complaint Behavior: An 
Indonesian Perspective, Marketing Intelligence \& Planning, 22(4), s.407-426.

Solvang, B. K. (2008), Customer Protest: Exit, Voice or Negative Wordof-Mouth, International Journal of Business Science and Applied Management, 3(1), s.1-19.

Strauss, J. ve Hill, D. J. (2001), Consumer Complaints by E-Mail: An Exploratory Investigation of Corporate Responses and Customer Reactions, Journal of Interactive Marketing, 15(1), s.63-73.

Sujithamrak, S. ve Lam, T. (2005), Relationship between Customer Complaint Behavior and Demographic Characteristics: A Study of Hotel Restaurants' Patrons, Asia Pacific Journal of Tourism Research, 10(3), s.289-307.

Varinli, İ. ve Çatı, K. (2010), Güncel Pazarlama Yaklaşımlarından Seçmeler, Ankara: Detay Yayınları.

Weun, S., Beatty, S. E. ve Jones, M. A. (2004), The Impact of Service Failure Severity on Service Recovery Evaluations AndpostRecovery Relationships, Journal of Services Marketing, 18(2), s.133-146.

Zeelenberg, M. ve Pieters, R. (1999), Comparing Service Delivery to what Might Have Been Behavioral Responses to Regret and Disappointment, Journal of Service Research, 2(1), s.86-97. 